University of Nebraska - Lincoln

DigitalCommons@University of Nebraska - Lincoln

\title{
Metals fate and transport modelling in streams and watersheds: state of the science and USEPA workshop review
}

\author{
B. S. Caruso \\ U.S. Environmental Protection Agency, Caruso.brian@epa.gov \\ T. J. Cox \\ $C D M$
}

R. L. Runkel

U.S. Geological Survey

M. L. Velleux

Colorado State University - Fort Collins

K. E. Bencala

U.S. Geological Survey

See next page for additional authors

Follow this and additional works at: https://digitalcommons.unl.edu/usgsstaffpub

Part of the Earth Sciences Commons

Caruso, B. S.; Cox, T. J.; Runkel, R. L.; Velleux, M. L.; Bencala, K. E.; Nordstrom, D. K.; Julien, P. Y.; Butler, B. A.; Alpers, Charles N.; Marion, A.; and Smith, K. S., "Metals fate and transport modelling in streams and watersheds: state of the science and USEPA workshop review" (2008). USGS Staff -- Published Research. 484.

https://digitalcommons.unl.edu/usgsstaffpub/484

This Article is brought to you for free and open access by the US Geological Survey at DigitalCommons@University of Nebraska - Lincoln. It has been accepted for inclusion in USGS Staff -- Published Research by an authorized administrator of DigitalCommons@University of Nebraska - Lincoln. 


\section{Authors}

B. S. Caruso, T. J. Cox, R. L. Runkel, M. L. Velleux, K. E. Bencala, D. K. Nordstrom, P. Y. Julien, B. A. Butler, Charles N. Alpers, A. Marion, and K. S. Smith 


\section{Metals fate and transport modelling in streams and watersheds: state of the science and USEPA workshop review}

\author{
B. S. Caruso, ${ }^{1 *, \dagger}$ T. J. Cox, ${ }^{2}$ \\ R. L. Runkel, ${ }^{3 \dagger}$ \\ M. L. Velleux, ${ }^{4}$ \\ K. E. Bencala, ${ }^{5 \dagger}$ \\ D. K. Nordstrom, ${ }^{6 \dagger}$ \\ P. Y. Julien, ${ }^{4}$ B. A. Butler, ${ }^{7}$ \\ C. N. Alpers ${ }^{8 \dagger}$ A. Marion ${ }^{9}$ \\ and K. S. Smith ${ }^{3 \dagger}$ \\ ${ }^{1}$ U.S. Environmental Protection \\ Agency, Denver, Colorado, USA \\ ${ }^{2}$ CDM, Denver, Colorado, USA \\ ${ }^{3}$ U.S. Geological Survey, Denver, \\ Colorado, USA \\ ${ }^{4}$ Colorado State University, Fort \\ Collins, Colorado, USA \\ ${ }^{5}$ U.S. Geological Survey, Menlo Park, \\ California, USA \\ ${ }^{6}$ U.S. Geological Survey, Boulder, \\ Colorado, USA \\ ${ }^{7}$ Colorado School of Mines, Golden, \\ Colorado, USA \\ ${ }^{8}$ U.S. Geological Survey, Sacramento, \\ California, USA \\ ${ }^{9}$ University of Padua, Padua, Italy
}

*Correspondence to:

B. S. Caruso, U.S. Environmental Protection Agency, Denver, Colorado, USA.

E-mail: Caruso.brian@epa.gov

${ }^{\dagger}$ The contribution of B. S. Caruso, R. L. Runkel, K. E. Bencala, D. K. Nordstrom, C. N. Alpers and K. S. Smith to this article was prepared as part of their official duties as United States Federal Government employees.

\section{Introduction and Background}

Metals pollution in surface waters from point and non-point sources (NPS) is a widespread problem in the United States and worldwide (Lofts et al., 2007; USEPA, 2007). In the western United States, metals associated with acid mine drainage (AMD) from hardrock mines in mountainous areas impact aquatic ecosystems and human health (USEPA, 1997a; Caruso and Ward, 1998; Church et al., 2007). Metals fate and transport modelling in streams and watersheds is sometimes needed for assessment and restoration of surface waters, including mining-impacted streams (Runkel and Kimball, 2002; Caruso, 2003; Velleux et al., 2006). The Water Quality Analysis Simulation Program (WASP; Wool et al., 2001), developed by the US Environmental Protection Agency (USEPA), is an example of a model used for such analyses. Other approaches exist and appropriate model selection depends on site characteristics, data availability and modelling objectives. However, there are a wide range of assumptions, input parameters, data requirements and gaps, and calibration and validation issues that must be addressed by model developers, users and decision makers. Despite substantial work on model development, their successful application has been more limited because they are not often used by decision makers for stream and watershed assessment and restoration. Bringing together scientists, model developers, users and decision makers should stimulate the development of appropriate models and improve the applicability of their results.

To address these issues, the USEPA Office of Research and Development and Region 8 (Colorado, Montana, North Dakota, South Dakota, Utah and Wyoming) hosted a workshop in Denver, Colorado on February 13-14, 2007. The workshop brought together approximately 35 experts from government, academia and consulting to address the state of the art for modelling metals fate and transport, knowledge gaps and future directions in metals modelling. It focused on modelling metals in high-altitude streams, rivers and watersheds impacted by mine waste that are common in the western United States and require remediation. For example, there are over 100000 abandoned or inactive mining sites across the United States, encompassing over 500000 acres of land that may eventually require characterization and remediation, including the possible application of stream or watershed metals fate and transport modelling (USEPA, 1997a).

This article provides a general overview of the state of the science on modelling metals fate and transport in streams and watersheds, including a review of presentations and discussions at the USEPA workshop. It builds on previous summaries of metals fate and transport models in aquatic systems, including USEPA (1997b, 2007), Allen (2002), Paquin et al. (2003), Nordstrom (2004) and Maest et al. (2005).

\section{Equilibrium Modelling}

Geochemical codes for equilibrium modelling, such as MINTEQ (MINEQL + WATEQ, where MINEQL is MINeral EQuiLibrium, 


\section{B. S. CARUSO ETAL.}

WATEQ is WATer EQuilibrium), are the basis of most reactive metals transport models for receiving waters. MINTEQA2 is an equilibrium speciation program for calculating the equilibrium composition of dilute aqueous solutions. It provides mass distribution among dissolved, sorbed and precipitated species under a variety of conditions (Allison et al., 1991). Visual-MINTEQ (Gustafson, 2004) has the same capabilities as MINTEQA2, with additional modules and databases for metals complexation with dissolved organic carbon (DOC) and metals sorption onto hydrous manganese oxides (HMO). Nordstrom (2004) reviews low-temperature geochemical process modelling using WATEQ4F, a public domain code that computes aqueous speciation and saturation indices and uses a frequently updated thermodynamic database (e.g. Nordstrom and Archer, 2003).

The PHREEQC (pH and REdox EQuilibria in C) code simulates metals geochemistry and equilibrium speciation with one-dimensional reactive transport in aqueous environments (Parkhurst and Appelo, 1999). It has been used extensively for modelling groundwater systems, it includes both ion association and Pitzer specific interaction codes, and rigorously simulates surface complexation reactions. PHREEQC provides an excellent description of surface complexation in the laboratory, but an extension to field settings is needed. It currently lacks the ability to simulate metals sorption to organic compounds, but offers a generalized kinetic capability. PHAST (PHREEQC and Solute Transport) is a three-dimensional extension of PHREEQC to groundwater systems (Parkhurst $e t$ al., 2004).

\section{Toxicity Modelling}

Setting of metals criteria has been complicated by the focus of regulators on a single total concentration value for each metal of concern without understanding the many confounding factors affecting metals toxicity. Most published experimental data for metals has shown no correlation between total metals concentrations, by themselves, and toxicity ( $\mathrm{Di}$ Toro et al., 2001). Correlations are seen only when a more mechanistic representation of the various environmental factors affecting bioavailability is applied. The last 20 years have seen significant work on metals toxicity assessment and development of the biotic ligand model (BLM; USEPA, 1999; Di Toro et al., 2001; WERF, 2007). The BLM provides an important link between metals concentration modelling and risk assessment. It converts calculated concentrations to 'toxic units' (ratio of predicted concentrations to toxicity levels) and incorporates the 'three $\mathrm{Cs}$ ' of bioavailability: concentration, competition (for biotic ligand sites) and complexation (with dissolved organic matter and aqueous ligands such as carbonate from alkalinity). The Windermere Humic Aqueous Model (WHAM6; Tipping, 1994; Lofts and Tipping, 1998) calculates metal speciation in the BLM, and includes sorption/desorption to organic and inorganic solids, precipitation and complexation.

The BLM bases biological toxicity on sediment and water column concentrations and incorporates major determinants of metal bioavailability (e.g. DOC and sulphide) and metal toxicity (e.g. alkalinity, $\mathrm{pH}$, hardness). Pore water concentrations are predicted as functions of the sediment-bound mass using equilibrium partitioning since the former determine toxicity. BLMs have been developed for copper, silver (Di Toro et al., 2001; Santore et al., 2001) and zinc (Santore et al., 2002), and are under development for cadmium, nickel and lead (CSME, 2006). Adams (2006) used the BLM to study the fate of copper at the Leadville/California Gulch Superfund Site, Colorado. Carbonaro (1999) modelled metal sulphide fluxes from sediments and metal binding to natural organic matter (NOM) for application to the BLM. His use of a linear free energy relationship model is an advancement over the current NOM/metals simulations employed by WHAM and the current BLM.

\section{Stream Modelling}

Unique and complex metals modelling issues associated with USEPA Region 8 and the Rocky Mountains include prevalence of mining impacts with multiple and variable point and NPS loadings, high gradients of receiving streams, significant hyporheic zone interactions, snowmelt-driven hydrology and naturally occurring background metals loads. Most USEPA stream metals modelling has used WASP (Wool et al., 2001), sometimes in conjunction with the Metals Exposure and Transformation Assessment (META4) module (Medine et al., 2002). Caruso (2003) and Caruso and Cox (2008) provide examples of WASP's use for restoration planning in a miningimpacted mountain stream, the Upper Tenmile Creek Mining Area Superfund Site, Montana. WASP has also been used to evaluate sediment water interactions (Caruso, 2004) and total maximum daily loads (TMDLs) in Tenmile Creek (Caruso, 2005). WASP is a box/compartment stream water quality code applicable in one, two, or three dimensions. It uses a lumped partition coefficient $\left(K_{\mathrm{D}}\right)$ for simulating metals equilibrium speciation between single particulate and dissolved compartments (Figure 1). Despite considerable uncertainty associated with $K_{\mathrm{D}}$ values (USEPA, 1989; Bethke and Brady, 2000; Caruso, 2004), they can be estimated from laboratory adsorption/desorption batch testing of actual contaminated stream benthic sediments (Caruso, 2004). Default values can also be obtained from the literature (e.g. Allison and Allison, 2005). The latest version (WASP8) simulates sorption to different sorbents (clays, sands and organic solids) and represents the oxidation/reduction process explicitly. The $K_{\mathrm{D}}$ approach in WASP is not the optimum way to model reactive metals fate and 
transport where pH-dependent sorption and precipitation reactions are involved, such as streams severely impacted by AMD.

In response, USEPA developed the META4 module for WASP4 (Medine et al., 2002), although it is not yet available in the general WASP release. META4 simulates equilibrium reactions and slower kinetic processes, including metals adsorption/desorption, precipitation, ion exchange and complexation. Environmental controls on these processes may be included, such as site-specific mineral and sediment characteristics, and concentrations of iron oxyhydroxides for sorption of metals and pH. WASP4/META4 has been used for the Alamosa River and Summitville Mine Superfund Site (Medine and Martin, 2002; Medine et al., 2002), and North Fork Clear Creek (NFCC), part of the Clear Creek/Central City Superfund Site, Colorado (Medine, 2003). Results for NFCC highlight the need for multi-pronged remediation efforts, including reduction in point source releases, waste pile stabilization, erosion controls, contaminated sediment removal and $\mathrm{pH}$ neutralization. A user-friendly graphical interface for WASP4/META4 is a future development need.

An example application uses both WASP4/META4 and Visual-MINTEQ to compare simulation of particulate metals concentrations in NFCC. Unlike WASP4/ META4, Visual-MINTEQ simulates equilibrium speciation only, and does not include transport (neither downstream nor vertical settling). Metals processes in this system are dominated by sorption and/or coprecipitation with hydrous ferric oxides (HFO) and (to a lesser extent) HMO, as well as complexation with DOC (Butler, 2005; Butler et al., 2008). The
WASP4/META4 program used includes only metals sorption to HFO, while Visual-MINTEQ also includes sorption to $\mathrm{HMO}$ and complexation with DOC. WASP4/META4 performed better for simulating high-flow conditions, likely due to incorporation of particulate transport, while Visual-MINTEQ performed better under low-flow conditions. WASP4/ META4 could also be improved by including DOC complexation, and perhaps sorption to HMO. For this stream, both programs seemed to lack representation of an additional sorbent (for zinc) besides HFO and HMO.

One-Dimensional Transport with Equilibrium Chemistry (OTEQ) (Runkel et al., 1999) combines the stream transport capability of OTIS (One-Dimensional Transport with Inflow and Storage, Runkel, 1998) and the geochemistry capability of MINTEQ (Figure 2). Transport mechanisms include advection, dispersion and transient storage [temporary detainment of solutes in pools and eddies (surface storage) and in porous areas of the streambed (hyporheic exchange); Bencala, 2005)]. Geochemical processes are simulated with equilibrium speciation equations for sorption/desorption and precipitation/dissolution. A key advantage is explicit simulation of interactions between pH, metal oxide precipitation (e.g. HFO) and subsequent sorption of other metals onto HFO. OTEQ will soon be public domain software available from the US Geological Survey (USGS). Examples of its application for mined watersheds include evaluation of remedial alternatives for Mineral Creek and the Summitville Mine Superfund Site (Runkel and Kimball, 2002; Ball et al., 2004), and estimating premining water quality in Red Mountain Creek, Colorado (Runkel et al., 2007). Potential enhancements

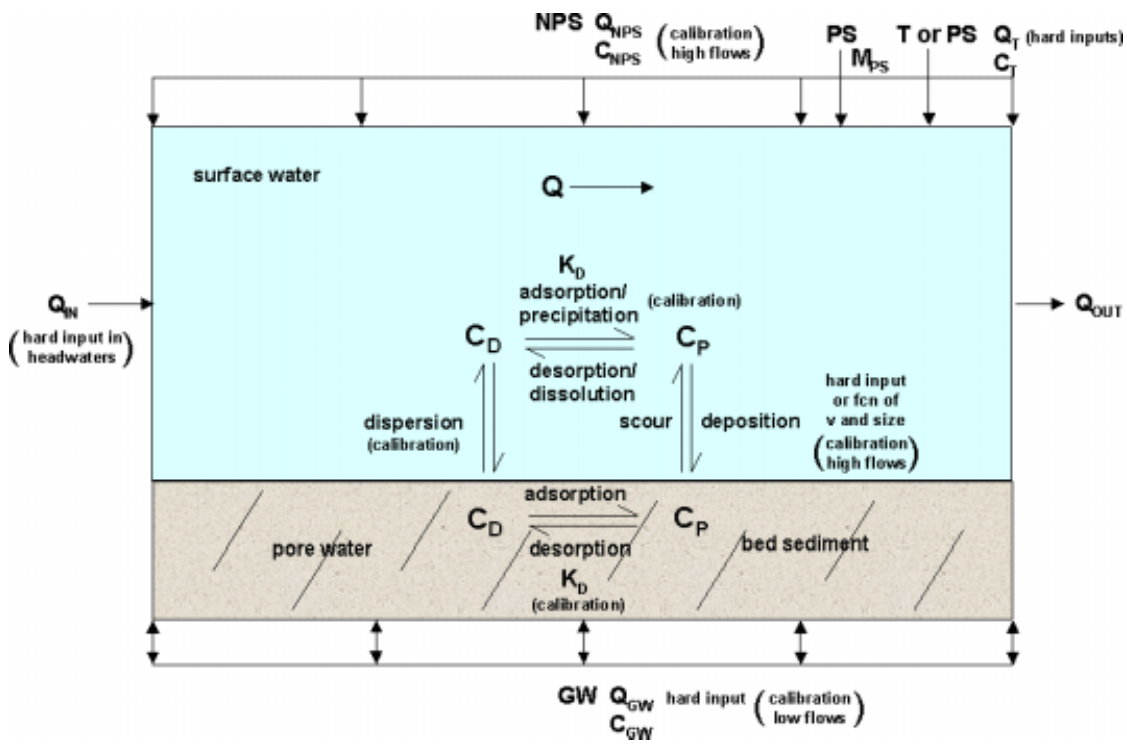

Figure 1. Schematic diagram of major metals fate and transport processes in WASP. $Q$ is streamflow in the stream-(modelled) segment. $Q_{\mathrm{IN}}$ is streamflow into segment. $Q_{\mathrm{OUT}}$ is streamflow out of segment. NPS is non-point source pollution. $Q_{\mathrm{NPS}}$ is NPS flow into stream. $C_{\mathrm{NPS}}$ is metal concentration in $Q_{\mathrm{NPS}}$. PS is point source pollution. $M_{\mathrm{PS}}$ is metal mass in PS flowing into stream. T is tributary. $Q_{\mathrm{T}}$ is flow of T or PS into stream. $C_{\mathrm{T}}$ is metal concentration in $Q_{\mathrm{T}}$. $\mathbf{G W}$ is groundwater. $Q_{\mathrm{GW}}$ is $\mathbf{G W}$ flow into or out of stream. $C_{\mathrm{GW}}$ is metal concentration in $Q_{\mathrm{GW}} \cdot C_{\mathrm{D}}$ is dissolved metal concentration in stream or bed pore water. $C_{\mathrm{P}}$ is particulate metal concentration in stream or bed pore water. $K_{\mathrm{D}}$ is equilibrium partition coefficient. Hard input includes values input to model that are not estimated using the model or used for calibration 


\section{B. S. CARUSO ETAL.}

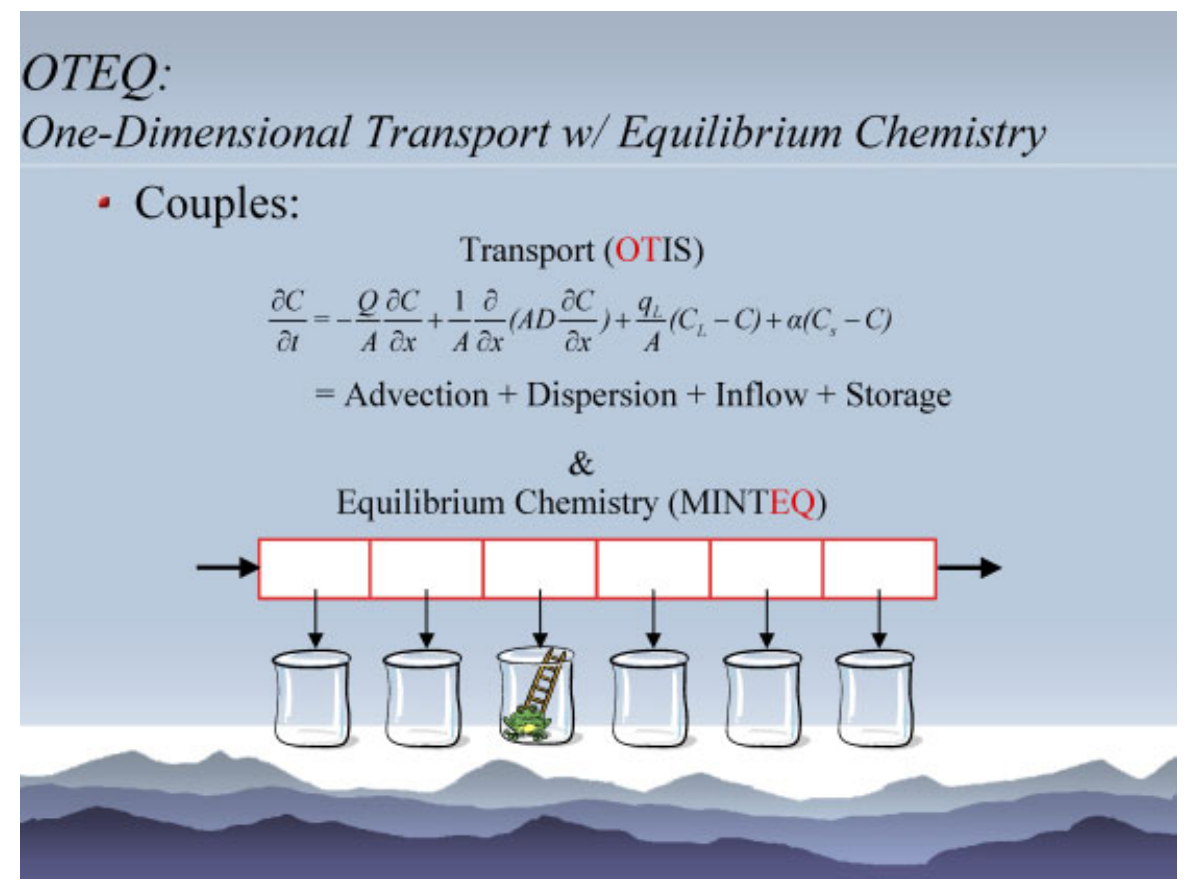

Figure 2. OTEQ combines the stream transport capability of OTIS and the geochemical capability of MINTEQ. Solutes are transported downstream subject to the physical processes of advection, dispersion, inflow and storage. Geochemical calculations within each stream segment quantify sorption and precipitation/dissolution reactions under the assumption of chemical equilibrium

include incorporation of kinetically limited degassing, oxidation and reduction, and nutrient and DOC interactions.

Transient storage in fast-responding surface dead zones and the upper hyporheic layer is well represented by the exponential residence time distribution (Hart, 1995) used with the Transient Storage Model (TSM). The TSM is therefore well suited for shortterm processes, justifying its use to derive transport properties from conservative tracer tests (e.g. OTIS, Runkel, 1998). However, the TSM and stream tracer approach do not adequately characterize exchange at long time scales, such as those associated with deep hyporheic zones (Harvey et al., 1996; Zaramella et al., 2006). Hyporheic exchange plays a role in attenuating mining-derived metals (Zaramella et al., 2006; Gandy et al., 2007). Deep hyporheic exchange and horizontal hyporheic flows induced by planimetric variations (e.g. cut-off flow at meanders) follow a residence time distribution that differs substantially from an exponential distribution (Marion et al., 2003; Zaramella et al., 2003; Boano et al., 2006). Since long-term tracer tests involving deep hyporheic flows and horizontal hyporheic flows are costly (e.g. Jonsson et al., 2004), modelling may be the only way to estimate long-term retention of substances in a riverine environment. The Solute Transport in Rivers (STIR) program modifies the TSM by separating storage processes at different temporal and spatial scales (Zaramella et al,, in review). STIR may contribute to improved metals modelling via consideration of transport and long time-scale storage in deeper hyporheic zones. Statistical properties of contaminant residence times in different physical compartments are described by applying multiple convolution (Marion and Zaramella, 2005). Tracer tests and experimental work can be used to calibrate different parts of the model independently.

The Center for the Study of Metals in the Environment (CSME) at the University of Delaware is developing a Unit World Model (UWM) for metals behaviour that can be used to assess both exposure/fate and effects/bioavailability (CSME, 2006). The UWM is based on fugacity and regional models developed for organic chemicals (Mackay, 1979, 1991; Mackay et al., 1992), and incorporates the BLM. CSME is developing a UWM for metals in rivers and streams where probabilistic methods capture the variability and uncertainty associated with stream metals in simulations of loadings and dilution. Probability distributions of measured upstream concentrations and flows are used to calculate downstream (mixed) concentration probability distributions, as well as settling and resuspension of particulate metals and downstream transport of both dissolved and particulate forms. The UWM's uniqueness for rivers and streams lies in its probabilistic handling of loads and dilution and the conversion to toxicity via the BLM.

A UWM is also being developed for lakes and reservoirs, with simultaneous solution of flux balance and chemical equilibrium equations using the Tableau Input Coupled Kinetics Equilibrium Transport (TICKET) model (Farley et al., 2008). The program simulates a single, well-mixed water column overlying a sediment layer and includes both 
metals speciation dynamics (partitioning, precipitation, complexation and organic carbon and sulphur cycling) and biological toxicity calculations based on the BLM.

Visual-MINTEQ and the BLM have been used to model data from the mining-impacted NFCC, Colorado (Butler, 2005; Butler et al., 2008; Ranville et al., 2005). Downstream transport and variations were not considered. Manganese, zinc and sulphate showed clear correlations with hydrology, with peak concentrations during low flows and minimum concentrations during high flows (snowmelt) along with an 'early flush' spike at the beginning of snowmelt. Copper and iron exhibited sharper variations and less seasonal trend, and were more closely correlated with storm events. These metals appeared to be dominated by the solid phase in this system. Toxicity simulation results for zinc showed large variability, with peaks during the early high-flow period. Negative correlation between toxicity and hardness levels was also observed. The study showed that the BLM approach is an improvement over past practices of setting criteria based on hardness only.

Finally, considerations of the numerical limitations associated with stream solute transport modelling are important for current and future model applications and development (e.g. Cox and Runkel, in review). Techniques for circumventing such problems as numerical dispersion and loss of mass conservation, including Lagrangian numerical methods, are well described in the literature and merit consideration for future model development.

\section{Watershed Modelling}

Recent watershed models of metals fate and transport use geographical information system (GIS) based physical data to describe topographic and drainage characteristics. The CASCade 2 Dimensional SEDiment (CASC2D-SED) program simulates watershedscale sediment transport from sheet and rill erosion (Johnson, 1997; Johnson et al., 2000; Julien and Rojas, 2002). Results from the Goodwin Creek Watershed, Mississippi, indicated that hydrology can be simulated accurately at a grid size of up to $1000 \mathrm{~m}$, while sediment simulations are best for grid sizes less than 100 m (Rojas Sánchez, 2002; Rojas et al., in review).

The Two-dimensional Runoff, Erosion, and eXport (TREX) program simulates metals transport at the watershed scale. TREX evolved from CASC2D-SED, adding chemical transport and fate dynamics from the WASP and In-place Pollutant eXport (IPX) (InPlace Pollutant eXport water quality modelling framework; Velleux et al., 2001) programs (Velleux, 2005; Velleux et al., 2006, Figure 3). Overland erosion is simulated using a modified version of the Universal Soil Loss Equation, while a modified Engelund and Hansen equation models channel erosion as a function of channel hydraulics and sediment particle characteristics. Metals speciation is simulated using

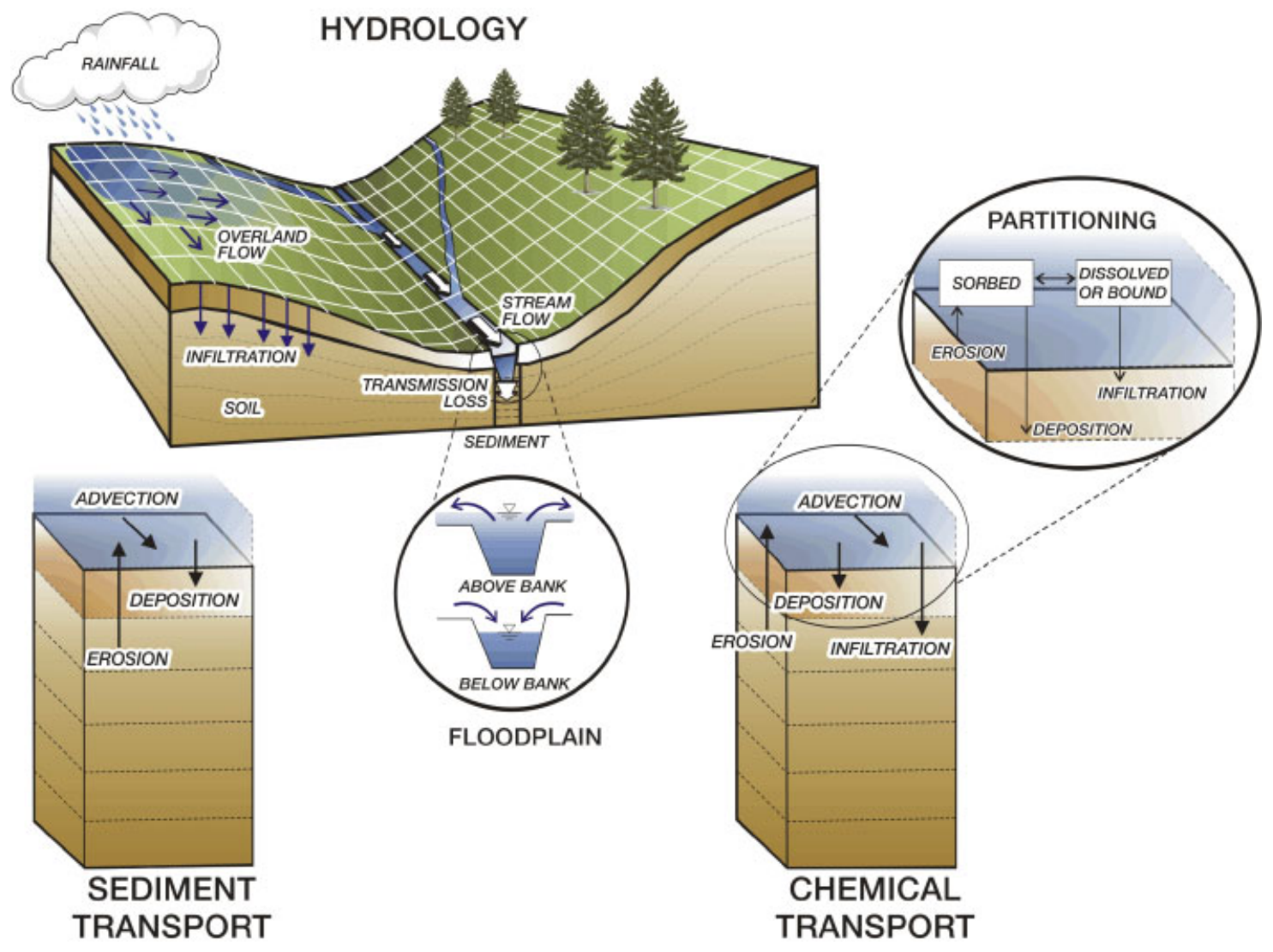

Figure 3. TREX model overview for hydrologic, sediment transport and chemical transport processes 


\section{B. S. CARUSO ETAL.}

$K_{\mathrm{D}}$. TREX has been applied to the California Gulch, Colorado mine-impacted watershed (Velleux, 2005; Velleux et al., 2006). A principal advantage of a fully distributed watershed model is the opportunity to identify key source areas within the watershed, such as waste piles that contribute most to chemical transport. The study showed that many of the simulated concentrations, particularly total suspended solids, exhibit a hysteresis effect with rising limb concentrations significantly greater than those on the falling limb. Future TREX development efforts will focus on an improved snowmelt algorithm, incorporating surface and groundwater interactions, and continuous simulation capabilities.

The US Bureau of Reclamation has used TREX to simulate extreme storms and resulting flood hydrographs in the Upper Arkansas River Basin, Colorado (England, 2006; England et al., 2007). A Monte Carlo-based approach demonstrated TREX's ability to simulate runoff in large $\left(12000 \mathrm{~km}^{2}\right)$ watersheds. Storm events as large as the Probable Maximum Precipitation and Probable Maximum Flood could be simulated (England et al., 2007). The work is relevant to metals modelling due to potentially large metal loads during extreme events in mountain watersheds with intense summer thunderstorms.

A watershed metals transport program coupling a generalized fate and transport module (Contaminant Transport Transformation and Fate, CTT\&F) with a spatially distributed watershed hydrology code has been developed by the US Army Corps of Engineers to simulate transport of metals from explosive compounds (Johnson and Zhong, 2006). The water quality module includes four-phase equilibrium partitioning (dissolved, precipitated, sorbed to sediment particles, and complexed with DOC), and up to seven different biochemical transformation processes, such as biodegradation and photolysis. Downstream advection and dispersion are also simulated. The program is more generalized and flexible with respect to water quality than either CASC2D SED or TREX. It has been used to simulate the transport of metals derived from explosives in the Camp Shelby Watershed, Mississippi (Johnson and Zhong, 2006).

\section{Geoenvironmental Modelling and Site Characterization}

In addition to these more conventional models, descriptive models of the environmental behaviour of different mineral-deposit types, or geoenvironmental mineral-deposit models (GEMs) (du Bray, 1995; Seal and Foley, 2002; Seal and Hammarstrom, 2003), may assist screening-level prediction of metals sources and transport in mined watersheds. GEMs are compilations of relevant data and premised on the definition of different mineral-deposit types according to similarities in geologic characteristics, which in turn result in similar environmental impacts (Plumlee, 1999).
They provide information on potential environmental effects of unmined mineralized areas, and on mine sites and mineral processing sites, based on empirical data from geologically similar sites. Metals of potential environmental concern and characteristic wastewater compositions in these areas can be anticipated using GEMs (Plumlee et al., 1999). Acid-generating and neutralizing potential also can be forecast for different mineral deposits, and bioaccessibility of metals can be assessed. While not a substitute for sitespecific data, GEMs can guide acquisition of traditional data by defining critical geologic variables and identifying primary potential environmental impacts (Schmiermund et al., 2006). GEMs can highlight environmental challenges associated with particular mineral deposits, which impact permitting, developing and closing mines.

Adequate site characterization is critical for providing appropriate data and ranges of values for fate and transport model development, input and evaluation. Substantial spatial and temporal variability in flows and metals concentrations and loads in western mountain streams impacted by mine waste must be considered in characterization and model input (Caruso and Cox, 2008). For example, metals concentrations in near-neutral pH mountain streams can vary considerably over a diurnal cycle due to several chemical and biological processes, including temperature-dependent adsorption/desorption reactions (Nimick et al., 2003; Gammons et al., 2005). Many studies of AMD have used tracer injection and synoptic sampling to assess the spatial distribution of metal loads to streams (Kimball et al., 2002), which can be input to programs such as OTEQ. Hyporheic exchanges defined by tracer studies in conjunction with stream and shallow well sampling indicated a mixture of source waters in the hyporheos in Mineral Creek, Colorado, contributing variable solute loads to the stream (Bencala et al., 2006). Infrequent vertical advective upwelling in the studied reach is consistent with hyporheic flows with significant longitudinal (down-valley) components. The TSM has been effective in characterizing hyporheic exchanges of solutes, primarily through interpretation of field data. Studies of solutes in the hyporheic zone have increased rapidly over the last decade, indicating increased recognition of these areas as important components of stream ecosystems. Future work should focus on a better understanding of the variable timescales of different types and downstream locations of hyporheic exchanges, catchment physical (and measurable) properties that determine flow paths and the overall impacts of hyporheic exchanges on catchment hydrology (Bencala, 2006).

Isotope tracers have been used in assessing metals sources and groundwater flow paths to streams for subsequent model input. For example, multiple isotopes were used in research at the Mary Murphy Mine, Colorado, indicating inflow to mine workings primarily through groundwater recharge from 
snowmelt and the presence of multiple groundwater flow systems (Hazen et al., 2002). Isotope data also enabled the identification of a specific underground source area for metals contamination in receiving waters.

\section{Mercury Modelling}

Mercury (Hg) modelling is gaining increased attention due to widespread contamination of surface waters in the western United States. Hg sources in watersheds include wet and dry atmospheric deposition from both long-range (e.g. intercontinental) and shorter-range transport from industrial sources such as coal-fired power plants, and local sources such as urban and mining areas. However, development of $\mathrm{Hg}$ fate and transport models faces many challenges. $\mathrm{Hg}$ codes range from simple spreadsheets (Brown et al., 2007) to more complex programs. Alpers et al. (in review) used the LOAD ESTimator (LOADEST - Runkel et al., 2004) to model $\mathrm{Hg}$ loads in a mining-impacted watershed in California (Alpers et al., 2005, 2006). Sources of $\mathrm{Hg}$ in California watersheds include high background levels (coastal ranges), $\mathrm{Hg}$ mines and gold mines (Hg lost during processing). LOADEST's empirical regressions describe contaminant loads as functions of flow and time. There was a positive correlation between methyl $\mathrm{Hg}$ and stream temperature, and highest $\mathrm{Hg}$ concentrations were measured during summer low flows. There was also an apparent seasonal variability in the relationship between $\mathrm{Hg}$ concentration and stream discharge, and hysteresis was evident. Incorporating this behaviour into LOADEST is a potential area of future work. In general, this empirical approach appears to be a good option when only downstream loads are of interest (rather than upstream mechanisms) and when both concentration and flow data are abundant.

Simple mass-balance spreadsheet models have been used for $\mathrm{Hg}$ studies. Ambrose et al. (2005) modelled mercury fluxes and concentrations in a Georgia watershed receiving atmospheric deposition by combining the Watershed Characterization System with a $\mathbf{H g}$ transport module developed from the spreadsheetbased IEM-2M model (USEPA, 1997c), and a more detailed, field-scale terrestrial $\mathrm{Hg}$ runoff model (Tsiros and Ambrose, 1999). In-stream transport was modelled using the Mercury Delivery Spreadsheet (Ambrose and Wool, 2001) and WASP-Hg parameterized from the WASP6 toxic chemical module (Wool et al., 2001). Brown et al. (2007) used USEPA's spreadsheet-based Ecological Risk Assessment for the Fate of Mercury (SERAFM) program for $\mathrm{Hg}$ in Steamboat Creek and a constructed wetland in Nevada. USEPA also evaluated the regional predictive capacity of a process-based $\mathrm{Hg}$ exposure model (Regional-Mercury Cycling Model [R-MCM]), applied to 91 Vermont and New Hampshire lakes and ponds (Knightes and Ambrose, 2007).
Although simple $\mathrm{Hg}$ simulation modules are available in MINTEQ and the current version of WASP, they lack mechanistic representation of many key processes associated with $\mathrm{Hg}$ in aquatic environments, including air-water interface exchange and water column speciation (Loux, 2005). Confounding factors affecting exchange rates specific to $\mathrm{Hg}$ include the difficulty of measuring gaseous $\mathrm{Hg}$ due to the sensitivity of analytical equipment to sunlight (Loux, 2001, 2004) and the significant diel variation of aqueous $\mathrm{Hg}$ (Loux, 2000). Ionic Hg species in aqueous solutions undergo a large suite of competitive equilibrium reactions with environmental ligands such as hydroxides, chlorides and sulphides (Loux, in press). MINTEQ simulates the aqueous speciation of $\mathbf{H g}$ adequately, but more data are required to define the large number of equilibrium constants (Loux, 2005).

\section{Workshop Discussion}

Past environmental impact statements (EISs) for hardrock mines, in which water quality impacts were characterized and predicted using modelling and experimental work, were reviewed by Kuipers et al. (2006). Methods, models and associated uncertainties for predicting water quality at hardrock mines and used in these EISs were also summarized (Maest et al., 2005). Of the 71 mines reviewed, nearly $90 \%$ had some type of site-specific geochemical characterization of waste piles in support of their EISs. Most characterizations combined static (single snapshot), kinetic (long-term and time-variable) and short-term leach tests to evaluate waste contamination potential. Over $50 \%$ used numerical modelling to predict water quantity, quality or both. None used what could be considered a comprehensive watershed model; however, various components of small watershed dynamics were modelled using combinations of focused hydrologic (e.g. HEC-1, MODFLOW) and/or water quality (e.g. PHREEQC, MINTEQ) models. Of the 15 mines with exceedances of surface water quality standards, no exceedances (given the planned mitigation) were predicted at 11 sites at the time of the EIS. In other words, nearly $75 \%$ 'got it wrong' using a variety of predictive methods. One recommendation was that proprietary models should not be used to support EISs because they are generally not available for review by others. A process scheme was also recommended for developing mining site models in support of mitigation planning. A key to successful modelling of these sites is a quantification of uncertainty (Kuipers et al., 2006).

One primary question is 'are existing metals modelling tools good enough?' to meet the needs of the regulatory, scientific and engineering communities tackling metals contamination problems. The consensus was that existing stream modelling tools are, for the most part, 'good enough'. The lumped $K_{D}$ approach is probably valid over a narrow range of systems, possibly including those where precipitation reactions are 


\section{B. S. CARUSO ETAL.}

not dominant. However, the more sophisticated alternatives (e.g. META4, OTEQ) are generally adequate for systems that fall outside this range. Nonetheless, these models and codes are 'living' tools that continue to be updated and enhanced. In this vein, the term 'model validation' was discouraged as it implies a final 'stamp of approval' for a model to be used without the discretion required. 'Model evaluation' may be more appropriate for describing the broad approach of applying, testing and refining these models and codes for better performance with time and for evolving needs.

While the necessary numerical tools may be available, data to adequately test, evaluate, parameterize and further refine these models are severely limited. The rate of model development has outpaced supporting data collection, primarily due to cost and other resource constraints. In particular, there has been little opportunity to perform 'post auditing' on models and codes due to a lack of both long-term data sets and funding. Future efforts should focus on data collection, as well as experimental controlled studies, designed specifically to test, evaluate and better parameterize existing modelling tools. The concept of a 'study' watershed for collaborative, long-term model development and evaluation was discussed. General lack of support from agency management and decision makers for model application and evaluation, due to a number of factors, was also a major impediment to further successful model development and use.

Existing watershed models and codes need further testing and evaluation using real data. However, collection of such data is more complicated for watersheds compared to streams. There are more parameters to quantify, and many of these, such as antecedent soil conditions and groundwater organic carbon concentrations, are difficult to measure. Truly calibrated watershed water quality models are hard to find in past work. One approach for watershed model calibration and evaluation utilizes output probability distributions as a basis of comparison rather than single-scenario, deterministic results. Bioavailability of predicted concentrations should also be included in such evaluations. Tracers, both added and natural, may assist watershed model calibration as they can help define both hydrologic pathways and specific contaminant sources.

Improvements in the use and accuracy of numerical models for mining-impacted and mountain areas are needed. Such models should guide sampling programs, and model development and testing should iterate between modelling and data collection. Models and codes should also be applied and evaluated more often, with the proper empirical support by the regulatory community. Skepticism needs to be overcome through further model evaluation, education and increased interaction between scientists/model developers and regulatory decision makers. Well-executed modelling studies have the potential to contribute to greater success and long-term cost savings in monitoring and remedial activities. As a component of these activities, the cost of the modelling can be a fraction of the total investment.

\section{Conclusion}

Other significant points include the following:

- Hg, which has garnered a lot of attention by USEPA recently, is in a 'different category' than other metals. It is more complex, requires significant research and model development and also needs additional data collection for model development and application.

- An inventory, and comparison, of both available metals modelling tools and available data sets would be very valuable.

- DOC is an often-overlooked parameter in data collection, given its importance to metals modelling and toxicity assessments.

- Modelling programs are valuable tools for interpreting existing data and understanding processes, in addition to projecting future conditions.

- USEPA should identify 'benchmark' models/codes and ensure their maintenance, documentation and updating.

\section{Acknowldgements}

The authors would like to thank the other participants of the USEPA Workshop: Rich Carbonaro, Dominic DiToro, John England, Kevin Farley, James Halgren, Marcella Hutchinson, Billy E. Johnson, Nick Loux, Ann Maest, James Martin, Al Medine, Roger Olsen, David Parkhurst, Kevin Rader, Jim Ranville, Dan Reeder, Andrew Sagen, Seema Shah-Fairbank, Philip Verplanck, Katie Walton-Day, and Mike Wireman.

\section{References}

Adams MK. 2006. Applicability of the biotic ligand model for mining influenced waters and the influence of variations in natural organic matter characteristics on copper toxicity to Ceriodaphnia dubia. MS thesis, Colorado School of Mines: Golden, CO, T-6107.

Allen HE. 2002. Bioavailability of Metals in Terrestrial Ecosystems: Importance of Partitioning for Bioavailability to Invertebrates, Microbes and Plants, ISBN 1-880611-46-5. SETAC Press: Pensacola, FL; 158 pp.

Allison JD, Allison TL. 2005. Partition Coefficients for Metals in Surface Water, Soil, and Waste. Prepared for U.S. EPA Office of Research and Development: Washington, DC, EPA/600/R-05/074.

Allison JD, Brown DS, Novo-Gradac KJ. 1991. MINTEQA2/PRODEFA2, A Geochemical Assessment Model for Environmental Systems: Version 3.0 Users' Manual. U.S. EPA, Athens, Georgia, EPA/600/391/021.

Alpers CN, Hunerlach MP, Marvin-DiPasquale MC, Antweiler RC, Lasorsa BK, De Wild JF, Snyder NP. 2006. Geochemical Data for Mercury, Methylmercury, and Other Constituents in Sediments from Englebright Lake, California, 2002: U.S. Geological Survey Data Series 151, 95 pp. http://pubs.water.usgs.gov/ds151/. 
Alpers CN, Hunerlach MP, May JT, Hothem RL. 2005. Mercury contamination from historical gold mining in California, U.S. Geological Survey Fact Sheet 2005-3014, 6, http://water.usgs.gov/pubs/fs/ 2005/3014/.

Alpers CN, Saleh D, Meyer RW. In review. Mercury and methylmercury transport in a Sierra Nevada watershed contaminated by historical gold mining: the Bear River, California, Science of the Total Environment.

Ambrose RB Jr, Tsiros IX, Wool TA. 2005. Modeling mercury fluxes and concentrations in a Georgia watershed receiving atmospheric deposition load from direct and indirect sources. Journal of the Air \& Waste Management Association 55(5): 547-558.

Ambrose RB, Wool TA. 2001. Modeling tools used for mercury TMDLs in Georgia rivers. In Proceedings of the 2001 Georgia Water Resources Conference, Hatcher K (ed.). University of Georgia: Athens, GA; 532-535.

Ball JW, Runkel RL, Nordstrom DK. 2004. Evaluating remedial alternatives for the Alamosa River and Wightman Fork, near Summitville Mine, Colorado-Application of a reactive transport model to low- and high-flow simulations. In Environmental Sciences and Environmental Computing, vol. II, Zannetti P (ed.). The EnviroComp Institute: Fremont, California; 1-54.

Bencala KE. 2005. Hyporheic exchange flows. In Encyclopedia of Hydrological Sciences, vol. 3(10), Anderson MG (ed.). John Wiley \& Sons: Hoboken, New Jersey; 1-7, Chapter 113.

Bencala KE. 2006. Hyporheic exchange flows-hydrology challenges for biogeochemical understanding. Geophysical Research Abstracts 8: 01565, SRef-ID: 1607-7962/gra/EGU06-A-01565.

Bencala KE, Kimball BA, Runkel RL. 2006. Variability of Nearstream, Sub-surface Major-ion and Tracer Concentrations in an Acid Mine Drainage Environment. 87(52), Eos Trans. AGU Fall Meet. Suppl., Abstract B23A-1060.

Bethke CM, Brady PV. 2000. How the $K_{\mathrm{d}}$ approach undermines ground water cleanup. Ground Water 38: 435-443.

Boano F, Camporeale C, Revelli R, Ridolfi L. 2006. Sinuosity-driven hyporheic exchange in meandering rivers. Geophysical Research Letters 33: L18406, DOI: 10·1029/2006GL027630.

Brown S, Saito L, Knightes CD, Gustin M. 2007. Calibration and evaluation of a mercury model for a western stream and constructed wetland. Water Air and Soil Pollution 182(1-4): 275-290.

Butler B. 2005. Assessing the fate and transport of metals in a highgradient acid-mine drainage impacted mountain stream, North Fork Clear Creek, Colorado. PhD dissertation, Colorado School of Mines, Department of Environmental Science and Engineering: Golden, CO.

Butler BA, Ranville JF, Ross PE. 2008. Observed and modelled seasonal trends in dissolved and particulate $\mathrm{Cu}, \mathrm{Fe}, \mathrm{Mn}$, and $\mathrm{Zn}$ in a mining-impacted stream. Water Research 42(12): 3135-3145.

Carbonaro R. 1999. Modeling metal sulfide fluxes from sediments. MS thesis, Department of Environmental Engineering, Manhattan College: Riverdale, NY.

Caruso BS. 2003. Water quality simulation for planning restoration of a mined watershed. Water Air and Soil Pollution 150(1-4): 221-234.

Caruso BS. 2004. Modeling metals transport and sediment/water interactions in a mining-impacted mountain stream. Journal of the American Water Resources Association 40(6): 1603-1615.

Caruso BS. 2005. Simulation of metals total maximum daily loads and remediation in a mining-impacted stream. Journal of Environmental Engineering 131(5): 777-789.

Caruso BS, Cox TJ. 2008. Modeling effects of natural flow restoration on metals fate and transport in a mountain stream impacted by mine waste. Journal of the American Water Resources Association 44(3): 535-551.

Caruso BS, Ward RC. 1998. Assessment of nonpoint source pollution from inactive mines using a watershed-based approach. Environmental Management 22(2): 225-243.

Center for the Study of Metals in the Environment. 2006. Final Report. U.S. Environmental Protection Agency, University of Delaware (in press)
Church SE, von Guerard P, Finger SE (eds). 2007. Integrated investigations of environmental effects of historical mining in the Animas River Watershed, San Juan County, Colorado: U.S. Geological Survey Professional Paper 1651, 417-495.

Cox TJ, Runkel RL. In review. An Eulerian-Lagrangian numerical scheme for simulating streams with transient storage and a comparison of numerical methods. Journal of Environmental Engineering.

Di Toro DM, Allen HE, Bergman HL, Meyer JS, Paquin PR, Santore RC. 2001. Biotic Ligand Model of the acute toxicity of metals. I. Technical Basis. Environmental Toxicology and Chemistry 20: 2383-2396.

du Bray EA (ed.). 1995. Preliminary Compilation of Descriptive Geoenvironmental Mineral Deposit Models: U.S. Geological Survey Open-File Report 95-0831, (Available online at http://pubs.usgs.gov/ of/1995/ofr-95-0831/).

England JF. 2006. Frequency analysis and two-dimensional simulations of extreme floods on a large watershed. $\mathrm{PhD}$ dissertation, Colorado Sate University, Department of Civil Engineering: Fort Collins, CO.

England JF Jr, Velleux ML, Julien PY. 2007. Two-dimensional simulations of extreme floods on a large watershed. Journal of Hydrology 347(1-2): 229-241, DOI:10·1016/j.jhydrol.2007·09.034.

Farley KJ, Rader KJ, Miller BE. 2008. Tableau Input Coupled Kinetic Equilibrium Transport (TICKET) model. Environmental Science and Technology 42(3): 838-844.

Gammons CH, Nimick DA, Parker ST, Cleasby TE, McCleskey RB. 2005. Diel behavior of iron and other heavy metals in a mountain stream with acidic to neutral pH: Fisher Creek, Montana, USA Geochimica Et Cosmochimica Acta 69: 2505-2516.

Gandy CJ, Smith JWN, Jarvis AP. 2007. Attenuation of miningderived pollutants in the hyporheic zone: a review. Science of the Total Environment 373: 435-446.

Gustafson JP. 2004. Visual MINTEQ, Version 2.30: A Windows version of MINTEQA2, version 4.0 [WWW document]. URL http://www.lwr.kth.se/english/OurSoftware/Vminteq.

Hart DR. 1995. Parameter estimation and stochastic interpretation of the transient storage model for solute transport in streams. Water Resources Research 31(2): 323-328.

Harvey JW, Wagner BJ, Bencala KE. 1996. Evaluating the reliability of the stream tracer approach to characterize stream-subsurface water exchange. Water Resources Research 32(8): 2441-2451.

Hazen JM, Williams MW, Stover B, Wireman M. 2002. Characterization of acid mine drainage using a combination of hydrometric chemical and isotopic analyses, Mary Murphy Mine, Colorado. Environmental Geochemistry and Health 24(1): 1-22.

Johnson BE. 1997. Development of a storm event based two dimensional upland erosion model. PhD dissertation, Department of Civil Engineering, Colorado State University: Fort Collins, CO.

Johnson BE, Julien PY, Molnar DK, Watson CC. 2000. The twodimensional-upland erosion model CASC2D-SED. Journal of the American Water Resources Association 36(1): 31-42.

Johnson BE, Zhong Z. 2006. CTT\&F: Distributed Sources Chemical Transport, Transformation and Fate Sub-model, ERDC TN-EQT-06-1. U.S. Army Engineer Research and Development Center: Vicksburg, MS; 17.

Jonsson K, Johansson H, Wörman A. 2004. Sorption behaviour and long-term retention of reactive solutes in the hyporheic zone of stream. Journal of Environmental Engineering 130(5): 573-584, DOI: 10·1061/(ASCE)0733-9372(2004)130 : 5(573).

Julien PY, Rojas R. 2002. Upland erosion modeling with CASC2DSED. International Journal of Sediment Research 17(4): 265-274.

Kimball BA, Runkel RL, Walton-Day K, Bencala KE. 2002. Assessment of metal loads in watersheds affected by acid mine drainage by using tracer injection and synoptic sampling: Cement Creek, Colorado, USA. Applied Geochemistry 17: 1183-1207.

Knightes CD, Ambrose RB. 2007. Evaluating regional predictive capacity of a process-based mercury exposure model, RegionalMercury Cycling Model (R-MCM), applied to 91 Vermont and New Hampshire lakes and ponds, USA. Environmental Toxicology and Chemistry 26(4): 807-815. 


\section{B. S. CARUSO ETAL.}

Kuipers JR, Maest AS, MacHardy KA, Lawson G. 2006. Comparison of predicted and actual water quality at hardrock mines: the reliability of predictions in Environmental Impact Statements, Kuipers and Associates and Buka Environmental.

Lofts SE, Tipping E. 1998. An assemblage model for cation binding by natural particle matter. Geochimica Et Cosmochimica Acta 62(15): 2609-2625.

Lofts S, Chapman PM, Dwyer R, McLaughlin MJ, Schoeters I, Sheppard SC, Adams WJ, Alloway BJ, Antunes PMC, Campbel PGC, Davies B, Degryse F, De Vries W, Farley KJ, Garrett RG, Green A, Groenenberg BJ, Hale B, Harrass M, Hendershot WH, Keller A, Lanno R, Liang T, Liu W, Ma Y, Menzie C, Moolenaar SW, Piatkiewicz W, Reimann C, Rieuwerts JS, Santore RC, Sauve S, Schuetze G, Schlekat C, Skeaff J, Smolders E, Tao S, Wilkins J, Zhao F. 2007. Critical loads of metals and other trace elements to terrestrial environments. Environmental Science and Technology 41: 6326-6331.

Loux NT. 2000. Diel temperature effects on the exchange of elemental mercury between the atmosphere and underlying waters. Environmental Toxicology and Chemistry 19: 1191-1198.

Loux NT. 2001. Monitoring cyclical air-water elemental mercury exchange. Journal of Environmental Monitoring 3: 43-48.

Loux NT. 2004. A critical assessment of elemental mercury air/water mass transfer parameters. Journal of Chemical Speciation and Bioavailability 15: 47-51.

Loux NT. 2005. Modeling Monomethylmercury and Tributyltin Speciation with EPA's Geochemical Speciation Model MINTEQA2. U.S. Environmental Protection Agency: Publication No. EPA/600/R05/063: Athens, GA.

Loux NT. In press.An assessment of thermodynamic reaction constants for simulating aqueous environmental monomethylmercury speciation. Journal of Chemical Speciation and Bioavailability.

Mackay D. 1979. Finding fugacity feasible. Environmental Science and Technology 13: 1218-1223.

Mackay D. 1991. Multimedia Environmental Models. Lewis Publishers: Chelsea, MI.

Mackay D, Paterson S, Shiu WY. 1992. Generic models for evaluating the regional fate of chemicals. Chemosphere 24: 695-717.

Maest AS, Kuipers JR, Travers CL, Atkins DA. 2005. Predicting water quality at hardrock mines: Methods and models, uncertainties, and state-of-the-art, Kuipers and Associates and Buka Environmental.

Marion A, Zaramella M. 2005. A residence time model for streamsubsurface exchange of contaminants. Acta Geophysica Polonica 53(4): 527-538.

Marion A, Zaramella M, Packman AI. 2003. Parameter estimation of the Transient Storage Model for stream-subsurface exchange. Journal of Environmental Engineering 129(5): 456-463.

Medine AJ. 2003. Modeling the Effectiveness of Remedial Alternatives to Reduce Mine Waste Impacts on North Clear Creek, Colorado (Final Report), Prepared for USEPA, NRMRL-Land Remediation and Pollution Control, Cincinnati, OH, Order No. 2C-R351-NASA.

Medine AJ, Martin JL. 2002. Development of a Metal Exposure and Transformation Assessment Model for Use in Watershed Management and TMDL Analyses. In Proceedings of Watershed 2000, Water Environment Federation and British Columbia Water and Waste Association and Western Canada Water and Wastewater Association, July 8-12, Vancouver, British Columbia, Canada.

Medine AJ, Martin JL, Sopher EJ. 2002. Development of the metal speciation-based metal exposure and transformation assessment model (META4): application to copper and zinc problems in the Alamosa River, Colorado. In Fate and Transport of Chemicals in the Environment: Impacts, Monitoring and Remediation, Lipnick RL, Mason RP, Phillips ML, Pittman CU (eds). ACS Publications: Washington, $\mathrm{DC}$.

Nimick DA, Gammons CH, Cleasby TE, Madison JP, Skaar D, Brick CM. 2003. Diel cycles in dissolved metal concentrations in streams-Occurrence and possible causes. Water Resources Research 39(9): 1247-1263.

Nordstrom DK. 2004. Modeling low-temperature geochemical processes. In Treatise on Geochemistry, vol. 5, Holland HD, Turekian KK ex (eds)., Surface and Ground Water, Weathering, and Soils, Drever JI (ed.). Elsevier Pergamon: Amsterdam; 37-72.

Nordstrom DK, Archer DG. 2003. Arsenic thermodynamic data and environmental geochemistry. In Arsenic in Ground Water: Geochemistry and Occurrence, Welch AH, Stollenwerk KG (eds). Kluwer Academic Publishers: Dordrecht, Netherlands; 1-25, Chap. 1.

Paquin PR, Santore RC, Farley K, Di Toro DM, Wu KB, Mooney KG, Winfield RP. 2003. Metals in Aquatic Systems: A Review of Exposure, Bioaccumulation, and Toxicity Models (Aquatic Metals). SETAC Press: Pensacola, FL.

Parkhurst DL, Appelo CAJ. 1999. User's Guide to PHREEQC (version 2) - A Computer Program for Speciation, Batch-reaction, Onedimensional Transport, and Inverse Geochemical Calculations. U.S. Geological Survey, Water-Resources Investigations Report: Denver, Colorado; 99-4259, 312.

Parkhurst DL， Kipp KL， Engesgaard P， Charlton SR. 2004. PHAST - A Program for Simulating Ground-Water Flow, Solute Transport, and Multicomponent Geochemical Reactions. U.S. Geological Survey Techniques and Methods 6-A8, 154.

Plumlee GS. 1999. The environmental geology of mineral deposits. In The Environmental Geochemistry of Mineral Deposits, Reviews in Economic Geology, vol. 6A, Plumlee GS, Logsdon MJ (eds). Society of Economic Geologists, Inc.: Littleton, CO; 71-116.

Plumlee GS, Smith KS, Montour MR, Ficklin WH, Mosier EL. 1999. Geologic controls on the composition of natural waters and mine waters draining diverse mineral-deposit types. In The Environmental Geochemistry of Mineral Deposits, Reviews in Economic Geology, vol. 6B, Filipek LH, Plumlee GS (eds). Society of Economic Geologists, Inc.: Littleton, CO; 373-432.

Ranville JF, Butler BA, Ross PE. 2005. Application of the biotic ligand model to identify water quality parameters influencing aquatic metal toxicity in Clear Creek, Colorado. In Poster Presented at the 18th Annual Meeting of the Rocky Mountain Regional Chapter of the Society of Environmental Toxicology and Chemistry, Leadville, CO, April 1-2.

Rojas R, Velleux ML, Julien PY, Johnson BE. In press. Grid scale effects on watershed soil erosion models. Journal of Hydrologic Engineering.

Rojas Sánchez R. 2002. GIS based upland erosion modeling, geovisulatization and grid size effects on erosion simulations with CASC2D-SED. PhD dissertation, Colorado Sate University, Department of Civil Engineering: Fort Collins, CO.

Runkel RL. 1998. One-dimensional Transport with Inflow and Storage (OTIS): A Solute Transport Model for Streams and Rivers US Geological Survey Water-Resources Investigations Report 98-4018.

Runkel RL, Crawford CG, Cohn TA. 2004. Load Estimator (LOADEST): A FORTRAN Program for Estimating Constituent Loads in Streams and Rivers: U.S. Geological Survey Techniques and Methods Book 4, 69, Chapter A5, http://pubs.usgs.gov/tm/2005/tm4A5/.

Runkel RL, Kimball BA. 2002. Evaluating remedial alternatives for an acid mine drainage stream: Application of a reactive transport model. Environmental Science and Technology 36(5): 1093-1101.

Runkel RL, Kimball BA, McKnight DM, Bencala KE. 1999. Reactive solute transport in streams: a surface complexation approach for trace metal sorption. Water Resources Research 35(12): 3829-3840.

Runkel RL, Kimball BA, Walton-Day K, Verplanck PL. 2007. A simulation-based approach for estimating premining water quality: Red Mountain Creek, Colorado. Applied Geochemistry 22: 1899-1918.

Santore RC, Di Toro DM, Paquin RC, Allen HE, Meyer JS. 2001. A biotic ligand model for the acute toxicity of metals. II. Application to acute copper toxicity in freshwater fish and daphnia. Environmental Toxicology and Chemistry 20: 2397-2402.

Santore RC, Mathew R, Paquin PR, Di Toro DM. 2002. Application of the biotic ligand model to predicting zinc toxicity to rainbow trout, fathead minnow, and daphnia magna. Computational Biochemical Physiology 133C(1-2): 271-285.

Schmiermund RL, Lazo MC, Parnow CC. 2006. Application of geoenvironmental models to accelerated EIA and permitting processes for an Andean porphyry $\mathrm{Cu}-\mathrm{Au}$ deposit. In Proceedings of the $7^{\text {th }}$ 
International Conference on Acid Rock Drainage (ICARD7), St. Louis, March 26-30, 2006, 1903-1911.

Seal RR II, Foley NK (eds). 2002. Progress on Geoenvironmental Models for Selected Mineral Deposit Types: U.S. Geological Survey Open-file Report 02-195, (Available online at http://pubs.usgs.gov/ of/2002/of02-195/).

Seal RR II, Hammarstrom JM. 2003. Geoenvironmental models of mineral deposits: examples from massive sulphide and gold deposits. In Environmental Aspects of Mine Wastes, Short Course Handbook, vol. 31, Jambor JL, Blowes DW, Ritchie AIM (eds). Mineralogical Association of Canada: Ottawa; 11-50.

Tipping E. 1994. WHAM - a computer equilibrium model and computer code for waters, sediments, and soils incorporating a discrete site/electrostatic model of ion-binding by humic substances. Computers \& Geosciences 20(6): 973-1023.

Tsiros IX, Ambrose RB. 1999. An environmental simulation model for mercury transport and fate in small rural catchments. Chemosphere 39: 477-492.

USEPA (U.S. Environmental Protection Agency). 1989. Briefing Report to the EPA Science Advisory Board on the Equilibrium Partitioning Approach to Generating Sediment Quality Criteria, EPA 440/5-89-002.

USEPA. 1997a. EPA's National Hardrock Mining Framework. Office of Water: Washington, DC, EPA 833-B-97-003.

USEPA. 1997b. Compendium of Tools for Watershed Assessment and TMDL Development. Office of Wetlands, Oceans, and Watersheds: Washington, DC, EPA-841-8-97-006.

USEPA. 1997c. Mercury Study Report to Congress. U.S Government Printing Office: Washington, DC, EPA-452/R-97-004.

USEPA. 1999. Integrated Approach to Assessing the Bioavailability and Toxicity of Metals in Surface Waters and Sediments, A Report to the EPA Science Advisory Board. Office of Water, Office of Research and Development: Washington, DC, EPA-822-E-99-001.

USEPA. 2007. Framework for Metals Risk Assessment. Office of the Science Advisor: Washington, DC, EPA 120/R-07/001.
Velleux ML. 2005. Spatially distributed model to assess watershed contaminant transport and fate. PhD dissertation, Colorado State University Department of Civil Engineering: Fort Collins, CO.

Velleux ML, Julien PY, Rojas-Sanchez R, Clements WH, England JF. 2006. Simulation of metals transport and toxicity at a mine-impacted watershed: California Gulch, Colorado. Environmental Science and Technology 40: 6996-7004.

Velleux M, Westenbroek S, Ruppel J, Settles M, Endicott D. 2001. A User's Guide to IPX, the In-Place Pollutant Export Water Quality Modeling Framework, Version 2.7.4. U.S. Environmental Protection Agency, Office of Research and Development, National Health and Environmental Effects Research Laboratory, Mid-Continent Ecology Division, Large Lakes Research Station, Grosse Ile, Michigan. 179, EPA/600/R-01/079.

WERF (Water Environment Research Foundation). 2007. U.S. EPA recommends use of BLM for copper in water quality criteria. Progress Newsletter 18(3): 1-3, [Online: http://www.werf.orgPublications].

Wool TA, Ambrose RB, Martin JL, Comer EA. 2001. Water Quality Analysis Simulation Program (WASP) Version 6.0 Draft: User's Manual. U.S. Environmental Protection Agency, http://www.epa.gov/ athens/wwqtsc/html/wasp.html. Accessed April 2008.

Zaramella M, Marion A, Bottacin Busolin A. In review. Solute transport in rivers with surface and hyporheic storage: the STIR model. Water Resources Research.

Zaramella M, Marion A, Packman AI. 2006. Applicability of the Transient Storage Model to the hyporheic exchange of metals. Journal of Contaminant Hydrology 84: 21-35.

Zaramella M, Packman AI, Marion A. 2003. Application of the transient storage model to analyze advective hyporheic exchange with deep and shallow sediment beds. Water Resources Research 39(7): 1198, DOI:10·1029/2002WR001344. 